\title{
PENELISIKAN KONSEP MAKNA KONSEPTUAL DAN LEKSIKAL PADA ISTILAH BIDANG STRUKTUR BANGUNAN- TEKNIK SIPIL
}

\author{
Linda Sari Wulandari $^{1 \otimes}$, Erlyn Rosalina ${ }^{2}$, Eri Ester Khairas ${ }^{3}$ \\ 1,3Jurusan Teknik Sipil, Politeknik Negeri Jakarta, ${ }^{2}$ Jurusan Administrasi Niaga, Politeknik Negeri \\ Jakarta, Jalan Prof. Dr. G.A. Siwabessy, Kampus UI, Kota Depok, 16242.

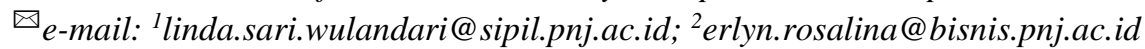

\begin{abstract}
This research aims to identify by exposing differences in meaning in words/terms used in the field of civil engineering, especially in building structures field, between existing meanings according to civil engineering field and in general meaning words (based on KBBI). The method used in this study is a descriptive qualitative method. This research was preceded by a literature study to obtain research data related to SNI civil engineering-building structure. The techniques used are listened and recorded techniques. The data source is a list of terms in the field of building structure contained in SNI. Data analysis is performed by agih and padan method. The outcomes of this study, obtained several terms in the field of building structures that have conceptual meaning and lexical meaning, such as base words tendon, diafragma, partisi, suffixes words like, tulangan, partisi, kebakaran, sambungan, and compound words like, tangga berjalan and cangkang berusuk. The conceptual meaning of these terms has more specific meaning towards the subject of building structure than its lexical meaning. Yet, both conceptual meaning and lexical meaning have similarities to the concepts it is used for. Thus, it can be noted that the use of vocabulary/term in a field has a special meaning according to the field, initially refers to a common concept first before being interpreted in a more particular field.
\end{abstract}

Keywords: conceptual meaning; lexical meaning; language varieties; building structure field; civil engineering.

\begin{abstract}
Abstrak
Penelitian ini bertujuan untuk mengidentifikasi dengan cara memaparkan perbedaan makna pada kata/istilah yang digunakan dalam bidang teknik sipil, khususnya bidang struktur bangunan, antara makna yang ada sesuai bidang teknik sipil dengan makna kata secara umum (berdasarkan KBBI). Metode yang digunakan dalam penelitian ini, yakni metode kualitatif deskriptif. Penelitian ini didahului dengan kajian kepustakaan untuk mendapatkan data penelitian terkait SNI struktur bangunan-teknik sipil. Teknik yang digunakan adalah teknik simak dan teknik catat. Sumber data berupa daftar istilah dalam bidang struktur bangunan yang terdapat dalam SNI. Analisis data dilakukan dengan metode agih dan metode padan. Hasil penelitian ini, yakni didapatkan beberapa istilah pada bidang struktur bangunan yang memiliki makna konseptual dan makna leksikal, seperti kata dasar tendon, diafragma, partisi, kata berimbuhan, seperti tulangan, partisi, kebakaran, sambungan, dan kata majemuk, seperti tangga berjalan dan cangkang berusuk. Makna konseptual pada istilah-istilah tersebut memiliki arti yang lebih spesifik ke arah bidang struktur bangunan dibanding dengan makna leksikalnya. Namun, baik makna konseptual maupun makna leksikalnya memiliki kemiripan konsep yang diacunya. Dengan demikian, dapat diketahui bahwa adanya penggunaan kosakata/istilah dalam suatu bidang yang memiliki makna khusus sesuai dengan bidangnya, pada mulanya mengacu pada konsep yang umum terlebih dahulu sebelum dimaknai lebih dalam lagi dalam bidang tertentu
\end{abstract}

Kata kunci: makna konseptual; makna leksikal; ragam bahasa; bidang struktur bangunan; teknik sipil

\section{Pendahuluan}

Bahasa yang terus mengalami perkembangan akan terus hidup. Bahasa yang hidup merupakan bahasa yang bersifat dinamis (Afjalurrahmansyah,
2018). Dinamis artinya mengamali perubahan sesuai dengan perkembangan zaman. Perkembangan zaman saat ini mengikuti perkembangan ilmu pengetahuan dan juga teknologi dalam 
segala bidang kehidupan. Bahasa yang digunakan saat ini akan selalu menyesuaikan seiring dengan perkembangan kehidupan dan kebutuhan manusia sebagai penutur bahasa (Afjalurrahmansyah, 2018).

Bahasa Indonesia merupakan salah satu bahasa yang bersifat dinamis karena bahasa Indonesia mampu untuk dapat menyeseuaikan diri dengan perkembangan kehidupan dan kebutuhan penutur bahasa. Perkembangan dan kebutuhan penutur bahasa dalam menggunakan bahasa Indonesia, salah satunya terlihat dari adanya penambahan kosakata-kosakata baru. Kosakata yang muncul dalam bahasa Indonesia memiliki pemaknaan yang berbeda-beda dalam setiap bidang. Terkadang penggunaan kosakata pada spesifik bidang tertentu, sudah memiliki makna yang berbeda dengan pemaknaan yang ada di luar bidang tersebut sehingga seiring dengan perkembanan bahasa, pemaknaan pada unsur-unsur bahasa, misalnya, pada tataran kata ini harus juga dapat diketahui secara lebih dalam lagi, karena mungkin saja makna saat ini berbeda dengan makna pada masa sebelumnya.

Kata merupakan satuan bahasa yang memiliki satu pengertian; atau deretan huruf yang diapit oleh dua buah spasi dan mempunyai satu arti (Chaer, 1994). Sebuah kata memiliki sebuah konsep. Namun, seiring dengan perkembangan ilmu pengetahuan dan teknologi, konsep yang terkandung dalam sebuah kata itu bisa saja mengacu pada lebih dari satu makna/arti. Satu kata yang sama, baik yang digunakan dalam suatu bidang dan di luar bidang tertentu, dapat memiliki satu konsep yang sama, tetapi secara makna kata, suatu kata yang digunakan dalam suatu bidang tertentu selalu mengandung perbedaan makna/arti dengan makna kata dari luar bidang tersebut.

Makna merupakan hubungan antara bentuk dan barang (hal yang diacunya) (Soedjito, 1988). Seperti yang sudah dijelaskan sebelumnya, bahwa suatu kata itu memiliki makna, artinya hubungan antara kata dan makna itu juga berkaitan dengan suatu konsep yang menjadi hal yang diacu dari makna tersebut. Makna dalam suatu kata dapat dilihat dari sudut pandang atau kriteria tertentu yang menyebabkan makna-makna tersebut dibedakan menjadi berbagai jenis makna, yaitu makna leksikal dan makna gramatikal, makna denotatif dan makna konotatif, makna konseptual dan makna asosiatif, makna idiom dan makna peribahasa (Chaer, 2009). Pada penelitian ini lebih terfokus pada makna konseptual. Makna konseptual adalah makna yang sesuai dengan referennya dan makna yang bebas dari asosiasi atau hubungan apa pun (Chaer, 2009: 72). Jadi, dapat dikatakan bahwa makna konseptual merupakan makna yang terkandung pada kata yang berdiri sendiri. Makna konseptual sama seperti makna referensial, makna leksikal, dan makna denotatif. Misalnya kata sawah memiliki makna 'ladang'. Namun, dalam penelitian ini akan dibahas makna konseptual yang terkandung dalam satu kata yang sama, tetapi dapat dimaknai secara konseptual dalam bidang teknik sipil dan juga makna kata secara umum (berdasarkan makna leksikal dalam KBBI).

Hal tersebut sebenarnya berkaitan dengan penggunaan kata dalam ragam bahasa. Ragam bahasa adalah variasi bahasa menurut penggunaannya yang dibedakan menurut topik, hubungan pelaku, dan medium pengungkapan (Kridalaksana, 2006). Ragam bahasa yang diteliti dalam penelitian ini adalah ragam bahasa 
Indonesia berdasarkan topiknya, yaitu bidang teknik sipil. Di dalam bidang teknik sipil, terdapat kosakata-kosakata dalam bahasa Indonesia yang bentuk katanya sama, mengacu pad konsep yang sama, namun memiliki makna yang berbeda antara makna kata dalam bidang teknik sipil dengan makna kata berdasarkan KBBI.

Penelitian terhadap makna kata sudah banyak dilakukan, tetapi penelitian terkait makna kata pada bidang teknik sipil, khususnya, kata/istilah dalam struktur bangunan belum ada yang meneliti. Penelitian makna kata yang sudah pernah dilakukan oleh Widjayanto (2015) terkait makna konseptual dan makna asosiatif pada teks lagu Sheila on 7. Widjayanto (2015) hanya membedakan adanya kedua makna dan selanjutnya menghitung jumlah kata yang mengandung makna konseptual dan asosiatif. Hasil penelitian Widjayanto (2015) dapat menjadi rfeensi dalam penelitian ini dalam menganalisis makna konseptual pada objek penelitian berupa daftar istilah dalam bidang teknik sipil. Selanjutnya, penelitian makna kata juga sudah dilakukan oleh Damayanti (2019) terkait makna kata pada kemasan permen Relaxa. Hasil penelitiannya menunjukan adanya makna referensial, piktoral, emotif, dan makna pusat. Penelitian Damayanti (2019) dapat menjadi referensi penulis dalam membedakan makna konseptual dengan makna referensial karena kedua makna tersebut hampir mirip. Makna referensial digunakan untuk memaknai kata/istilah yang ada referennya di dunia nyata. Selain penelitian Widjayanto (2015) dan Damayanto (2019), ada pula penelitian Duerawee (2018) mengenai keluasan makna kata-kata dalam bahasa Indonesia. Hasil penelitiannya menunjukkan bahwa kata-kata dalam bahasa Indonesia memiliki makna yang luas dibandingan dengan bahasa Melayu. Penelitian yang dilakukan oleh Duewawee (2018) menjadi referensi peneliti dalam menggunakan metode padan dalam menganalisis makna kata.

Berdasarkan penelitian-penelitian terkait makna kata yang sudah dilakukan, ternyata memang belum ada yang melakukan penelitian terkait makna kata pada suatu bidang teknik. Padahal, dengan adanya revolusi industri 4.0 ini arah kemajuan teknologi ini pasti membawa dampak juga pada adanya istilah-istilah bidang teknik yang bisa jadi merupakan serapan dari bahasa asig atau memang dipadankan dengan istilah yang ada di Indonesia. Oleh karena itu, peneliti akan melakukan penelitian, khususnya, yang berkaitan dengan bidang struktur bangunan di Teknik Sipil. Istilah yang digunakan dalam bidang struktur bangunan teknik sipil ini merupakan istilah yang digunakan berdasarkan konsep yang sudah ada dalam bahasa Indonesia. Namun, makna kata atau istilah yang terkandung dalam teknik sipil itu lebih dispesifikan dengan penggunaannya dalam bidang teknik sipil.

Dengan demikian, peneliti dalam melakukan penelitan ini juga merumuskan masalah sebagai berikut (1) Apa saja bentuk kata/istilah yang terdapat digunakan dalam bidang struktur bangunan teknik sipil yang mengandung makna konseptual? (2) Bagaimana perbedaan antara bentuk makna konseptual dengan makna leksikal (berdasarkan KBBI) pada kata dalam bidang struktur bangunan teknik sipil? (3) Apakah makna konseptual dan makna leksikal (berdasarkan KBBI) pada kata/istilah bidang struktur bangunan teknik sipil mengacu pada konsep yang sama? 
Berdasarkan rumusan masalah tersebut, tujuan penelitian ini, yaitu untuk dapat mengidentifikasi dengan cara memaparkan perbedaan makna pada kata/istilah yang digunakan dalam bidang teknik sipil, khususnya bidang struktur bangunan, antara makna yang ada sesuai bidang teknik sipil dengan makna kata secara umum (berdasarkan KBBI). Struktur bangunan merupakan salah satu bidang teknik sipil yang paling tua dan juga di dalamnya terdapat banyak istilah/kata-kata, yang menurut peneliti memiliki makna yang lain di luar makna dalam bidang teknik sipil.

\section{Metode Penelitian}

Penelitian ini merupakan penelitian yang menggunakan metode kualitatif deksriptif. Artinya, hasil penelitian akan dipaparkan secara utuh dengan melakukan pendeskripsian terhadap data. Metode kualitatif deskriptif ini didukung dengan metode-metode atau teknikteknik lainnya dalam proses pengumpulan data dan penganalisisan data. Proses pengumpulan data dilakukan dengan menggunakan kajian kepustakaan, artinya peneliti mengumpulkan dari berbagai referensi. Sumber data yang menjadi objek penelitian adalah daftar kata/istilah pada bidang struktur bangunan gedung yang ada di dalam SNI 032847 beton bertulang, SNI 1729 baja, SNI 1726 gempa, SNI 1727 pembebanan. Di dalam standar-standar tersebut, setiap kata/istilah sudah ada di dalam daftar isilah yang juga sudah disertai dengan makna katanya berdasarkan pemaknaan dalam bidang teknik sipil. Peneliti menggunakan teknik simak dan teknik catat.

Teknik simak dilakukan dengan cara menyimak semua kata/istilah yang ada di dalam SNI-SNI yang berkaitan dengan struktur bangunan gedung, lalu dilanjutkan dengan teknik catat. Jadi, peneliti melakukan pencatatan kata/istilah sebagai data penelitian. Data yang digunakan dalam penelitian ini, yakni ada dalam tataran kata, baik yang hanya terdiri dari satu kata maupun berupa kata majemuk. Setelah data diperoleh dan dikumpulkan dalam bentuk tabulasi data. Selanjutnya, peneliti melakukan penganalisisan data. Analisis data dilakukan dengan metode agih dan metode padan.

Menurut Sudaryanto (1993), metode agih adalah metode yang menggunakan alat penentu bagian dari bahasa yang bersangkutan yang menjadi objek sasaran di dalam penelitian itu sendiri. Metode padan adalah metode/cara yang digunakan dalam upaya menemukan kaidah dalam tahap analisis data yang alat penentunya di luar, terlepas, dan tidak menjadi bagian dari bahasa (langue) yang bersangkutan. Alat penentu yang dimaksud menurut Sudaryanto (1993:15). Metode padan ini digunakan karena makna kata/istilah bidang struktur bangunan ini terkait dengan penggunannya dalam ragam bahasa berdasarkan pokok pembahasannya, yaitu bidang teknik sipil, yang digunakan oleh kelompok penutur bahasa yang bekerja/berprofesi di bidang teknik sipil, khususnya terkait bidang struktur bangunan gedung. Oleh karena itu, analisis ini berkaitan dengan pemahaman konsep di luar bahasa itu sendiri.

\section{Hasil dan Pembahasan}

Kata/istilah dalam bidang struktur bangunan merupakan bentuk dari ragam bahasa Indonesia berdasarkan bidang teknik sipil. Ragam bahasa tersebut digunakan dalam pokok bahasan yang berkaitan dengan bidang teknik sipil, terutama yang berkaitan dengan SNI yang berisi pembahasan mengenai struktur bangunan gedung. Kata/istilah 
yang ada di dalam SNI 032847 beton bertulang, SNI 1729 baja, SNI 1726 gempa, dan SNI 1727 pembebanan. memiliki arti/makna yang berbeda dengan arti/makna kata yang dikenal secara umum.

Kata/istilah yang digunakan dalam bidang struktur bangunan gedung mengandung makna konseptual. Makna konseptual, yaitu makna yang dimiliki oleh suatu kata/istilah yang apa adanya terlepas dari konteks atau asosiasi apapun. Sebenarnya, makna konseptual tersebut sama dengan makna leksikal. Namun, dalam penelitian ini, istilah makna leksikal digunakan untuk mengacu pada makna kata/istilah yang sesuai dengan makna di luar bidang struktur bangunan gedung teknik sipil. Oleh karena itu, makna leksikal lebih ditekankan pada hasil pemaknaan berdasarkan KBBI.

\section{Hasil}

Hasil dari penelitian ini merupakan bentuk tabulasi data dalam daftar tabel 1 berikut, terkait dengan kata/istilah dalam bidang struktur bangunan gedung yang memiliki makna konseptual yang pemaknaan/artinya berbeda dengan makna/arti dalam bentuk makna leksikalnya (berdasarkan KBBI).

Tabel 1. Daftar Kata/Istilah dalam Bidang Struktur Bangunan Gedung

\begin{tabular}{|l|l|l|}
\hline No. & $\begin{array}{l}\text { Daftar } \\
\text { Kata/Istilah }\end{array}$ & $\begin{array}{l}\text { Makna dalam Bidang Struktur } \\
\text { Bangunan Gedung }\end{array}$ \\
\hline 1. & tendon & $\begin{array}{l}\text { Elemen baja misalnya kawat baja, } \\
\text { kabel batang, kawat untai atau suatu } \\
\text { bundel dari elemen-elemen tersebut } \\
\text { yang digunakan untuk memberi } \\
\text { gaya prategang pada beton. }\end{array}$ \\
\hline 2. & diafragma & $\begin{array}{l}\text { Makna atap, lantai, membran atau } \\
\text { sistem bresing yang berfungsi } \\
\text { menyalurkan gaya-gaya lateral ke } \\
\text { elemen penahan vertikal. }\end{array}$ \\
\hline 3. & tulangan & $\begin{array}{l}\text { Batang baja berbentuk polos atau } \\
\text { berbentuk ulir atau berbentuk pipa } \\
\text { yang berfungsi untuk menahan gaya }\end{array}$ \\
\hline
\end{tabular}

\begin{tabular}{|c|c|c|}
\hline & & $\begin{array}{l}\text { tarik pada komponen struktur beton, } \\
\text { tidak termasuk tendon prategang, } \\
\text { kecuali bila secara khusus } \\
\text { diikutsertakan }\end{array}$ \\
\hline 4. & partisi & $\begin{array}{l}\text { Dinding interior nonstruktural yang } \\
\text { membentang horisontal dan vertikal } \\
\text { dari tumpuan yang satu ke tumpuan } \\
\text { yang lain }\end{array}$ \\
\hline 5. & kebakaran & $\begin{array}{l}\text { Pembakaran yang bersifat merusak, } \\
\text { seperti ditunjukkan oleh salah satu } \\
\text { atau semua hal berikut: sinar, } \\
\text { kobaran api, panas atau asap. }\end{array}$ \\
\hline 6. & sambungan & $\begin{array}{l}\text { Di antara dua elemen struktur yang } \\
\text { disatukan pada ujung-ujungnya } \\
\text { untuk membentuk suatu elemen } \\
\text { tunggal, yang lebih panjang }\end{array}$ \\
\hline 7. & $\begin{array}{l}\text { tangga } \\
\text { berjalan }\end{array}$ & $\begin{array}{l}\text { Semua elemen yang memikul beban } \\
\text { dinamis dari tangga berjalan harus } \\
\text { dirancang untuk beban impak dan } \\
\text { batas defleksi ditetapkan oleh } \\
\text { ASME A17.1. }\end{array}$ \\
\hline 8. & $\begin{array}{l}\text { cangkang } \\
\text { berusuk }\end{array}$ & $\begin{array}{l}\text { Struktur ruang yang bermaterial } \\
\text { betonnya terutama ditempatkan di } \\
\text { sepanjang garis-garis rusuk tertentu, } \\
\text { di mana daerah di antara rusuk- } \\
\text { rusuk tersebut diisi dengan pelat } \\
\text { tipis atau dibiarkan terbuka }\end{array}$ \\
\hline
\end{tabular}

Tabel di atas menunjukkan adanya delapan kata/istilah dalam bidang struktur bangunan gedung-teknik sipil yang memiliki makna tersendiri dalam bidang teknik sipil, yaitu kata tendon, diafragma, tulangan, partisi, kebakaran, sambungan, dan dua kata yang meruakan bentuk kata majemuk, yaitu tangga berjalan dan cangkang berusuk. Makna kata yang terkandung di dalam kata/istilah tersebut merupakan makna konseptual dari kata/istilah dalam bidang struktur bangunan gedung sesuai dengan sumber SNI-nya. Makna konseptual tersebut masih berkaitan dengan makna leksikal (makna berdasarkan KBBI) pada satu kata/istilah yang sama, yang akan dijelaskan pada bagian pembahasan.

\section{Pembahasan}

Tabel 1 menunjukkan adanya delapan data yang dianalisis dalam penelitian ini, yaitu kata tendon, diafragma, tulangan, partisi, kebakaran, sambungan, tangga berjalan dan cangkang berusuk. 
Kedepalan data tersebut berupa kata/istilah yang terdapat dalam SNI struktur bangunan gedung-teknik sipil. Kata/istilah tersebut sudah memiliki arti/makna kata konseptual dalam bidang teknik sipil, tetapi secara umum kedepalan kata tersebut juga memiliki makna leksikal (sesuai KBBI) yang berbeda dengan makna konseptual pada bidang struktur bangunan. Perbedaan antara makna konseptual dalam bidang struktur bangunan gedung dengan makna leksikal dalam KBBI pada kedelapan kata tersebut dijelaskan sebagai berikut.

Data 1: Tendon

Kata tendon termasuk ke dalam kategori kata nomina. Kata tendon memiliki makna konseptual dan makna leksikal yang perbedaannya dapat dilihat sebagai berikut.

Tabel 2. Makna Konseptual dan Leksikal Kata Tendon

\begin{tabular}{|c|c|c|}
\hline Kata & $\begin{array}{lr}\text { Makna } & \text { Konseptual } \\
\text { sesuai } & \text { Bidang } \\
\text { Struktur } & \text { Bangunan }\end{array}$ & $\begin{array}{l}\text { Makna Leksikal } \\
\text { Berdasarkan KBBI }\end{array}$ \\
\hline Tendon & $\begin{array}{l}\text { elemen baja misalnya } \\
\text { kawat baja, kabel } \\
\text { batang, kawat untai atau } \\
\text { suatu bundel dari } \\
\text { elemen-elemen tersebut } \\
\text { yang digunakan untuk } \\
\text { memberi gaya } \\
\text { prategang pada beton }\end{array}$ & $\begin{array}{l}\text { urat keras yang } \\
\text { menghubungkan otot } \\
\text { dengan sendi atau } \\
\text { yang menghubungkan } \\
\text { otot dengan tulang }\end{array}$ \\
\hline
\end{tabular}

Tendon merupakan kata benda konkret. Menurut SNI 032847 mengenai beton bertulang, tendon adalah elemen baja misalnya kawat baja, kabel batang, kawat untai atau suatu bundel dari elemenelemen tersebut yang digunakan untuk memberi gaya prategang pada beton. Makna leksikal yang terdapat dalam KBBI (2016), tendon adalah urat keras yang menghubungkan otot dengan sendi atau yang menghubungkan otot dengan tulang.

Makna kata tendon yang diambil dari SNI 032847 terdapat pada kata kawat. Dalam KBBI (2016), kawat adalah tali yang dibuat dari logam. Makna leksikal kata tendon dalam KBBI (2016) terdapat pada kata urat. Urat memiliki arti bagian dalam tubuh yang menyerupai benang atau tali. Jadi, kata tendon dalam istilah bidang struktur bangunan dengan tendon dalam makna leksikal memiliki makna konseptual yang berhubungan melalui kata tali.

\section{Data 2: Diafragma}

Kata diafragma termasuk ke dalam kategori nomina. Kata diafragma memiliki makna konseptual dan makna leksikal yang perbedaannya dapat dilihat sebagai berikut.

Tabel 3. Makna Konseptual dan Leksikal Kata Diafragma

\begin{tabular}{|l|l|l|}
\hline Kata & $\begin{array}{l}\text { Makna Konseptual sesuai } \\
\text { Bidang Struktur } \\
\text { Bangunan }\end{array}$ & $\begin{array}{l}\text { Makna Leksikal } \\
\text { Berdasarkan } \\
\text { KBBI }\end{array}$ \\
\hline Diafragma & $\begin{array}{l}\text { Makna atap, lantai, } \\
\text { membran atau sistem } \\
\text { bresing yang berfungsi } \\
\text { menyalurkan gaya-gaya } \\
\text { lateral ke elemen penahan } \\
\text { vertikal }\end{array}$ & $\begin{array}{l}\text { Sekat antara rongga } \\
\text { dada dan rongga } \\
\text { perut (pada tubuh) }\end{array}$ \\
\hline
\end{tabular}

Diafragma merupakan kata benda konkret. Dalam bidang struktur bangunan teknik sipil melalui SNI 1727 tentang pembebanan, kata diafragma memiliki makna atap, lantai, membran atau sistem bresing yang berfungsi menyalurkan gaya-gaya lateral ke elemen penahan vertikal. Makna leksikal yang diambil dari KBBI (2016), diafragma merupakan kata benda yang artinya sekat antara rongga dada dan rongga perut (pada tubuh).

Makna kata diafragma yang terdapat pada SNI 1727 tentang pembebanan, terdapat pada kata membran. Membran adalah selaput, kulit tipis, atau lembaran bahan tipis yang merupakan pemisah. Makna leksikal kata diafragma dalam KBBI (2016), terdapat pada kata sekat. Sekat adalah sesuatu seperti dinding, kerai, dan sebagainya untuk membatasi atau 
memisahkan ruang (menjadi berpetakpetak). Saat makna dikaji lebih mendalam, kata diafragma memiliki makna konseptual yang berhubungan melalui kata dasar yang sama, yaitu pisah pada kata sekat dan pemisah pada kata membran. Jadi, kata diafragma memiliki makna konseptual melalui kata sekat dan membran.

Data 3: Tulangan

Kata tulangan termasuk ke dalam kategori nomina. Kata tulangan berasal dari kata dasar tulang yang mendapatkan sufiks -an. Kata tulangan memiliki makna konseptual dan makna leksikal yang perbedaannya dapat dilihat sebagai berikut.

Tabel 4. Makna Konseptual dan Leksikal Kata Tulangan

\begin{tabular}{|l|l|l|}
\hline Kata & $\begin{array}{l}\text { Makna Konseptual sesuai } \\
\text { Bidang Struktur } \\
\text { Bangunan }\end{array}$ & $\begin{array}{l}\text { Makna Leksikal } \\
\text { Berdasarkan } \\
\text { KBBI }\end{array}$ \\
\hline Tulangan & $\begin{array}{l}\text { Batang baja berbentuk } \\
\text { polos atau berbentuk ulir } \\
\text { atau berbentuk pipa yang } \\
\text { berfungsi untuk menahan } \\
\text { gaya tarik pada komponen } \\
\text { struktur beton, tidak } \\
\text { termasuk tendon prategang, } \\
\text { kecuali bila secara khusus } \\
\text { diikutsertakan. }\end{array}$ & $\begin{array}{l}\text { rangka atau } \\
\text { bagian rangka } \\
\text { abuh manusia } \\
\text { atau binatang }\end{array}$ \\
\hline
\end{tabular}

Tulangan merupakan kata benda konkret di dalam bidang struktur bangunan. Menurut SNI 032847 mengenai beton bertulang, tulangan memiliki arti batang baja berbentuk polos atau berbentuk ulir atau berbentuk pipa yang berfungsi untuk menahan gaya tarik pada komponen struktur beton, tidak termasuk tendon prategang, kecuali bila secara khusus diikutsertakan. Makna leksikal dalam KBBI (2016), tulangan memiliki kata dasar tulang yang memiliki arti rangka atau bagian rangka tubuh manusia atau binatang.

Dari SNI 032847, makna kata tulangan terdapat pada kata batang. Batang memiliki arti rangka sepeda kecuali roda.
Kata batang memiliki arti rangka. Dalam makna leksikal, kata tulangan yang memiliki kata dasar tulang, memiliki arti rangka. Dengan demikian, kata tulangan dalam istilah bidang struktur bangunan dengan makna leksikal memiliki makna konseptual yang berhubungan melalui kata rangka.

\section{Data 4: Partisi}

Kata partisi termasuk ke dalam kategori nomina. Kata partisi memiliki makna konseptual dan makna leksikal yang perbedaannya dapat dilihat sebagai berikut.

Tabel 5. Makna Konseptual dan Leksikal Kata Partisi

\begin{tabular}{|l|l|l|}
\hline Kata & $\begin{array}{l}\text { Makna Konseptual sesuai } \\
\text { Bidang Struktur Bangunan }\end{array}$ & $\begin{array}{l}\text { Makna Leksikal } \\
\text { Berdasarkan } \\
\text { KBBI }\end{array}$ \\
\hline Partisi & $\begin{array}{l}\text { dinding interior nonstruktural } \\
\text { yang membentang horisontal } \\
\text { dan vertikal dari tumpuan } \\
\text { yang satu ke tumpuan yang } \\
\text { lain }\end{array}$ & $\begin{array}{l}\text { dinding pemisah; } \\
\text { sekat }\end{array}$ \\
\hline
\end{tabular}

Partisi merupakan kata benda konkret. Menurut SNI 1726 mengenai gempa, partisi bermakna dinding interior nonstruktural yang membentang horizontal dan vertikal dari tumpuan yang satu ke tumpuan yang lain. Makna leksikal dalam KBBI (2016), partisi memiliki dinding pemisah; sekat.

Menurut SNI 1726, makna kata partisi terdapat pada kata dinding. Dalam makna leksikal, kata partisi memiliki arti kata dinding. Jadi, kata partisi dalam istilah bidang struktur bangunan dengan makna leksikal memiliki makna konseptual yang berhubungan melalui kata dinding.

\section{Data 5: Kebakaran}

Kata kebakaran merupakan kata dari kategori nomina. Kata kebakaran adalah kata berimbuhan ke-an. Kata kebakaran ini memiliki bentuk dasar bakar dari kategori verba, yang berarti menghanguskan 
(menyalakan/merusakkan) dengan api (KBBI). Kata kebakaran memiliki makna konseptual dan makna leksikal yang perbedaannya dapat dilihat sebagai berikut.

Tabel 6. Makna Konseptual dan Leksikal Kata Kebakaran

\begin{tabular}{|l|l|l|}
\hline Kata & $\begin{array}{l}\text { Makna } \\
\text { Konseptual sesuai } \\
\text { Bidang Struktur } \\
\text { Bangunan }\end{array}$ & $\begin{array}{l}\text { Makna Leksikal } \\
\text { Berdasarkan } \\
\text { KBBI }\end{array}$ \\
\hline kebakaran & $\begin{array}{l}\text { Pembakaran yang } \\
\text { bersifat merusak, } \\
\text { seperti ditunjukkan } \\
\text { oleh salah satu atau } \\
\text { semua hal berikut: } \\
\text { sinar, kobaran api, } \\
\text { panas atau asap }\end{array}$ & $\begin{array}{l}\text { pertanggungan } \\
\text { kebakaran (tentang } \\
\text { rumah dan } \\
\text { sebagainya yang } \\
\text { terbakar); bahaya } \\
\text { api; }\end{array}$ \\
\hline
\end{tabular}

Pada tabel nomor lima, terdapat kata kebakaran. Kebakaran masuk ke dalam kata benda konkret. Menurut SNI 1729 tentang baja, kebakaran adalah pembakaran yang bersifat merusak, seperti ditunjukkan oleh salah satu atau semua hal berikut: sinar, kobaran api, panas atau asap. Makna leksikal kata beton yang terdapat dalam KBBI (2016), kebakaran adalah pertanggungan kebakaran (tentang rumah dan sebagainya yang terbakar); bahaya api.

Makna kata kebakaran yang diambil dari SNI 1729 terdapat pada kata dasar bakar melalui kata pembakaran dan api. Makna leksikal kata kebakaran dalam KBBI terdapat pada kata dasar bakar dari kata kebakaran dan terbakar serta api. Jadi, kata kebakaran dalam istilah bidang struktur bangunan dengan kebakaran dalam makna leksikal memiliki makna konseptual yang berhubungan melalui kata pembakaran dengan kebakaran dan terbakar serta kata api.

Data 6: Sambungan

Kata sambungan termasuk ke dalam kategori nomina. Kata sambungan merupakan kata berimbuhan yang berasal dari kata dasar sambung dengan sufiks an. Kata sambung berkategori kata verba.
Berdasarkan KBBI, kata sambung berarti hubungan atau satukan. Jadi, kata sambung+ (-an) menjadi kata sambungan yang berarti hasil dari perbuatan menghubungkan/menyatukan. Kata sambungan memiliki makna konseptual dan makna leksikal yang perbedaannya dapat dilihat sebagai berikut.

Tabel 7. Makna Konseptual dan Leksikal Kata Sambungan

\begin{tabular}{|l|l|l|}
\hline Kata & $\begin{array}{l}\text { Makna Konseptual } \\
\text { sesuai Bidang Struktur } \\
\text { Bangunan }\end{array}$ & $\begin{array}{l}\text { Makna Leksikal } \\
\text { Berdasarkan } \\
\text { KBBI }\end{array}$ \\
\hline Sambungan & $\begin{array}{l}\text { Di antara dua elemen } \\
\text { struktur yang disatukan } \\
\text { pada ujung-ujungnya } \\
\text { untuk membentuk suatu } \\
\text { elemen tunggal, yang } \\
\text { lebih panjang }\end{array}$ & $\begin{array}{l}\text { Tambahan untuk } \\
\text { memanjangkan }\end{array}$ \\
\hline
\end{tabular}

Kata sambungan terdapat di dalam tabel nomor enam. Sambungan merupakan kata benda konkret. Dalam bidang struktur bangunan teknik sipil melalui SNI 1729 tentang baja, kata sambungan memiliki makna di antara dua elemen struktur yang disatukan pada ujungujungnya untuk membentuk suatu elemen tunggal, yang lebih panjang. Makna leksikal yang diambil dari KBBI (2016), diafragma merupakan kata benda yang artinya tambahan untuk memanjangkan.

Makna kata sambungan yang terdapat pada SNI 1729 tentang baja, terdapat pada kata panjang. Makna leksikal kata sambungan dalam KBBI, terdapat pada kata kerja memanjangkan. Kata memanjangkan memiliki kata dasar panjang. Jadi, kata sambungan memiliki makna konseptual melalui kata panjang dan memanjangkan.

Data 7: Tangga Berjalan

Istilah tangga berjalan digunakan dalam bidang struktur bangunan. Istilah tangga berjalan merupakan bentuk kalimat majemuk yang berdasarkan KBBI juga memiliki bentuk istilah lain, yakni ekskalator. Berdasarkan KBBI, tangga 
berjalan berarti tangga yang digerakkan turun naik oleh daya listrik. Istilah tangga berjalan harus dimaknai secara bersamaan tidak bisa kata perkata karena bila kata perkata maknanya tidak akan berterima. Istilah tangga berjalan memiliki makna konseptual dan makna leksikal yang perbedaannya dapat dilihat sebagai berikut.

Tabel 8. Makna Konseptual dan Leksikal Istilah Tangga Berjalan

\begin{tabular}{|l|l|l|}
\hline Kata & $\begin{array}{l}\text { Makna Konseptual sesuai } \\
\text { Bidang Struktur } \\
\text { Bangunan }\end{array}$ & $\begin{array}{l}\text { Makna Leksikal } \\
\text { Berdasarkan } \\
\text { KBBI }\end{array}$ \\
\hline $\begin{array}{l}\text { Tangga } \\
\text { berjalan }\end{array}$ & $\begin{array}{l}\text { Semua elemen yang } \\
\text { memikul beban dinamis } \\
\text { yang harus dirancang untuk } \\
\text { beban impak dan batas } \\
\text { defleksi ditetapkan oleh } \\
\text { ASME A17.1. }\end{array}$ & $\begin{array}{l}\text { tangga yang oleh daya } \\
\text { naik onan turun } \\
\text { listrik; eskalator }\end{array}$ \\
\hline
\end{tabular}

Data 8: Cangkang berusuk

Istilah cangkang berusuk digunakan dalam bidang struktur bangunan teknik sipil. Pemaknaan secara leksikal pada istilah cangkang berusuk berdasarkan KBBI, tidak seperti pemaknaan dari istilah tangga berjalan (yang dapat dimaknai dalam bentuk kesatuan istilah). Namun, dalam bidang teknik sipil, istilah cangkang berusuk dimaknai dalam bentuk kesatuan sebagai bentuk kata majemuk. Istilah cangkang berusuk memiliki makna konseptual dan makna leksikal yang perbedaannya dapat dilihat sebagai berikut.

Tabel 9. Makna Konseptual dan Leksikal Istilah Cangkang Berusuk

\begin{tabular}{|c|c|c|}
\hline Kata & $\begin{array}{l}\text { Makna } \\
\text { Konseptual } \\
\text { sesuai Bidang } \\
\text { Struktur } \\
\text { Bangunan }\end{array}$ & $\begin{array}{l}\text { Makna Leksikal } \\
\text { Berdasarkan } \\
\text { KBBI }\end{array}$ \\
\hline cangkang berusuk & $\begin{array}{l}\text { Struktur ruang } \\
\text { yang bermaterial } \\
\text { betonnya terutama } \\
\text { ditempatkan di } \\
\text { sepanjang garis- } \\
\text { garis rusuk } \\
\text { tertentu, di mana } \\
\text { daerah di antara } \\
\text { rusuk-rusuk }\end{array}$ & $\begin{array}{l}\text { Cangkang adalah } \\
1 \text { kulit telur; } 2 \\
\text { rumah siput atau } \\
\text { kerang; } 3 \text { kulit } \\
\text { keras yang } \\
\text { menutupi badan } \\
\text { (pada penyu, kura- } \\
\text { kura, ran } \\
\text { sebagainya); }\end{array}$ \\
\hline
\end{tabular}

\begin{tabular}{|l|l|l|}
\hline & $\begin{array}{l}\text { tersebut diisi } \\
\text { dengan pelat tipis } \\
\text { atau dibiarkan } \\
\text { terbuka. }\end{array}$ & $\begin{array}{l}\text { Rusuk adalah iga } \\
\text { (tulang-tulang dari } \\
\text { tulang belakang ke } \\
\text { tulang dada) }\end{array}$ \\
\hline
\end{tabular}

Cangkang berusuk masuk ke dalam kata benda konkret. Menurut SNI 032847, tentang beton bertulang, cangkang berusuk merupakan struktur ruang yang bermaterial betonnya terutama ditempatkan di sepanjang garis-garis rusuk tertentu, di mana daerah di antara rusuk-rusuk tersebut diisi dengan pelat tipis atau dibiarkan terbuka. Makna leksikal istilah cangkang berusuk yang terdapat dalam KBBI (2016) dipilah menjadi dua kata yaitu cangkang dan berusuk. Cangkang adalah 1 kulit telur; 2 rumah siput atau kerang; 3 kulit keras yang menutupi badan (pada penyu, kurakura, dan sebagainya). Sedangkan kata berusuk berasal dari kata dasar rusuk yang memiliki arti iga (tulang-tulang dari tulang belakang ke tulang dada).

Makna kata cangkang berusuk yang didapatkan dari SNI 032847 terdapat pada kata dasar pelat dan rusuk-rusuk. Makna leksikal istilah cangkang berusuk dalam KBBI (2016 terdapat pada kata dasar kulit keras dan tulang-tulang. Kata cangkang memiliki makna pelat, menurut istilah bidang struktur bangunan. Pelat adalah logam yang pipih dan tipis. Sedangkan dalam makna leksikal, kulit adalah lapisan yang ada di luar sekali. Jika ditelaah lebih dalam, pelat ini berfungsi untuk melapisi rusuk-rusuk bangunan. Jadi, secara garis besar, pelat ini memiliki konsep yang sama dengan kata kulit melalui kata melapisi walaupun tidak tertulis nyata atau tidak secara langsung menyebutkan kata melapisi di dalam kedua pemaknaan tersebut.

Selanjutnya, kata berusuk berasal dari kata rusuk. Menurut SNI, makna yang diambil difokuskan pada kata rusuk- 
rusuk. Rusuk-rusuk merupakan kata rusuk yang memiliki jumlah lebih dari satu atau banyak dari kata rusuk. Rusuk adalah tulang-tulang dari tulang belakang ke tulang dada. Makna leksikal dari kata dasar rusuk adalah tulang-tulang. Tulangtulang merupakan kata yang memiliki jumlah lebih banyak atau lebih dari satu. Jika dikaji lebih dalam maknanya, akan ditemukan kata yang sama yaitu tulang.

Jadi, kata cangkang adalah kata benda konkret yang memiliki makna konseptual yang saling berhubungan di antara istilah bidang struktur bangunan dan makna leksikal melalui kata pelat dan kulit. Lalu, kata berusuk memiliki makna konseptual di antara dua bidang yang diteliti melalui kata rusuk-rusuk dan tulang-tulang.

\section{Konsep yang Diacu dalam Makna Kata pada Kata/Istilah dalam Bidang Struktur Bangunan dengan Makna Kata Leksikal Berdasarkan KBBI}

Berdasarkan pembahasan dari kedelapan data di atas, yakni kata tendon, diafragma, tulangan, partisi, kebakaran, sambungan, tangga berjalan dan cangkang berusuk, dapat diketahui bahwa makna konseptual pada masing-masing istilah berdasarkan pemaknaan dalam bidang struktur bangunan mengacu pada konsep yang sama dengan pemaknaan kata berdasarkan makna leksikal pada KBBI.

Kata tendon dalam bidang struktur bangunan mengacu pada konsep kawat, sedangkan dalam KBBI mengacu pada konsep urat, meskipun kawat dan urat merupakan dua hal yang berlainan, tetapi antara kawat dan urat masih memiliki kesamaan fungsinya, yakni untuk memperkuat struktur. Selanjutnya, ada juga kata diafragma, kata diafragma dalam bidang struktur bangunan mengacu pada kata membran, sedangkan dalam KBBI mengacu pada kata sekat, antara membran dan sekat juga memiliki hubungan dalam pemaknaan, yakni membran ini berfungsi sebagai sekat. Lalu, ada kata partisi, kata partisi dalam bidang struktur bangunan mengacu pada konsep dinding. Konsep dinding ini diacu oleh makna kata konseptual maupun makna leksikal pada kata partisi.

Berikutnya, ada bentuk kata berimbuhan dalam bidang struktur bangunan, yakni kata tulangan, kebakaran, dan sambungan. Kata tulangan dalam bidang struktur bangunan mengacu pada konsep batang, sedangkan dalam KBBI mengacu pada konsep rangka. Baik batang maupun rangka, sebenernya keduanya memiliki kemiripan fungsi, yakni sama-sama digunakan sebagai penyangga. Lalu, kata kebakaran dalam bidang struktur bangunan mengacu pada konsep kerusakan karena api, konsep tersebut sama-sama digunakan baik dalam bidang struktur maupun pada makna leksikal dalam KBBI. Begitu pula dengan kata sambungan, kata sambungan dalam bidang struktur bangunan mengacu pada konsep menyatukan dua elemen, konsep tersebut juga sama dengan makna leksikal dalam KBBI, yakni konsep menyatukan, menambahkan, atau menjadikan panjang.

Selanjutnya, ada bentuk kata majemuk tangga berjalan dan cangkang berusuk dalam bidang struktur bangunan. Istilah tangga berjalan dalam bidang struktur bangunan mengacu pada konsep dinamis, sedangkan dalam bentuk makna leksikal berdasarkan KBBI mengacu pada konsep digerakkan. Sebenarnya, baik kata dinamis maupun digerakkan, kedua konsep tersebut memiliki kesamaan, yakni berkaitan dengan gerak. Lalu, yang terkahir adalah istilah cangkang berusuk. Cangkang berusuk dalam bidang struktur bangunan mengacu pada konsep pelat tipis dan rusuk, sedangkan konsep berdasarkan makna leksikal dalam KBBI mengacu pada konsep kulit keras dan tulang-tulang. Pelat tipis dan kulit keras 
merupakan dua konsep yang memiliki kesamaan, yakni lapisan luar yang keras, begitu juga antara konsep rusuk dan tulang yang memiliki kesamaan, yakni sebagai penyangga/penegak bentuk.

Berdasarkan penjelasan di atas, dapat diketahui bahwa kata-kata yang digunakan dalam bidang stuktur bangunan-teknik sipil, meski secara makna konseptual sesuai dengan bidangnya menunjukkan adaya perbedaan, tetapi setelah dianalisis lebih lanjut ternyata makna kata yang terkandung di dalamnya mengacu pada konsep yang sama dengan makna leksikal berdasarkan KBBI. Jadi, berdasarkan hasil analisis ini dapat diketahui bahwa penggunaan istilah/kata dalam bidang struktur bangunan, khususnya, kata/istilah tendon, diafragma, tulangan, partisi, kebakaran, sambungan, tangga berjalan dan cangkang berusuk, merupakan kata yang memiliki makna konseptual berdasarkan bidangnya dengan tetap mengacu pada konsep yang sama dengan makna leksikalnya (makna yang dapat dipahami oleh masyakarat umum). Hanya saja, pemaknaan konseptual sesuai dengan bidangnya itu lebih memperjelas makna kata yang terkandung dalam masing-masing istilah yang sesuai dengan fungsinya dalam bidang teknik sipil, khususnya, mengenai struktur bangunan.

\section{Kesimpulan}

Kata/istilah yang terdapat dalam bidang struktur bangunan-teknik sipil yang mengandung makna konseptual dalam penelitian ini antara lain kata dasar, seperti tendon, diafragma, partisi, kata berimbuhan, seperti tulangan, partisi, kebakaran, sambungan, dan kata majemuk, seperti tangga berjalan dan cangkang berusuk. Istilah-istilah tersebut mengandung makna konseptual berdasarkan bidang struktur bangunan teknik sipil dan juga makna leksikal berdasarkan KBBI. Makna leksikal berdasarkan KBBI pada istilah-istilah tersebut lebih bersifat umum, sedangkan makna konseptual berdasarkan pemaknaan sesuai bidang struktur bangunan lebih bersifat khusus pemaknaannya ke arah bidang struktur bangunan. Akan tetapi, konsep yang diacu pada makna konseptual berdasarkan bidang struktur bangunan ini mengacu pada konsep-konsep yang sama dengan makna yang terkandung dalam makna leksikalnya berdasarkan KBBI, hanya saja konsep pada makna konseptual tersebut lebih spesifik ke arah bidang struktur bangunan. Dengan demikian, dapat disimpulkan bahwa adanya penggunaan kosakata/istilah dalam suatu bidang yang memiliki makna khusus sesuai dengan bidangnya, pada mulanya mengacu pada konsep yang umum terlebih dahulu sebelum dimaknai lebih dalam lagi dalam bidang tertentu.

\section{Ucapan Terima kasih}

Penelitian ini mendapatkan hibah dana penelitian internal PNBP, UP2M Politeknik Negeri Jakarta, pada skim penelitian dosen pemula.

\section{Daftar Pustaka}

Afjalurrahmansyah. (2018). BAHASA ARAB DALAM BAHASA INDONESIA (Analisis Kritis terhadap Perubahan Makna Kata Serapan Bahasa Arab). Diwan : Jurnal Bahasa dan Sastra Arab. Vol.4 No. 1. DOI: https://doi.org/10.24252/diwan.v4i 1.4670 .

Chaer, A. (1994). Linguistik Umum. Jakarta: PT Rineka Cipta.

Chaer, A. (2009). Pengantar semantik bahasa Indonesia. Jakarta: PT Rineka Cipta.

Damayanti, R. (2019). Analisis Makna Kata pada Kemasan Permen Relaxa. Bahasa dan Sastra, 4(4). 
Retrieved

from

http://jurnal.untad.ac.id/jurnal/inde x.php/BDS/article/view/12206.

Duerawee, A. (2018). Keluasan Makna

Kata-kata Bahasa Indonesia dan

Bahasa Melayu Pattani yang

Digunakan oleh Mahasiswa

Thailand di Universitas

Muhammadiyah Surakarta.

Mabasan.

doi:10.26499/mab.v12i1.36.

Kridalaksana, H. (1989). Pembentukan

Kata dalam Bahasa Indonesia.

Jakarta: PT.Gramedia.

Sudaryanto. (1993). Metode dan Aneka

Teknik Analisis Bahasa: Pengantar

Penelitian Wahana Kebudayaan

secara Linguistis. Yogyakarta:

Duta Wacana University Press.

Soedjito. (1988). Kosakata Bahasa Indonesia. Jakarta: Gramedia.

Widjayanto, A. (2015). Makna

Konseptual dan Makna Asosiatif dalam Teks Lagu Sheila on 7. Jurnal Sastra Indonesia, 4(1). Retrieved from http://journal.unnes.ac.id/sju/index. $\mathrm{php} / \mathrm{jsi}$ 